\title{
ANALISIS PENERIMAAN ORANG TUA TERHADAP ANAK AUTIS DI KECAMATAN KELAPA LIMA KOTA KUPANG
}

\author{
Sance Mariana Tameon \\ Dosen STAKN Kupang \\ sancemariana82@gmail.com \\ Talita Tlonaen \\ Mahasiswa STAKN Kupang \\ talitatlonaen071@gmail.com
}

\begin{abstract}
Children who are born with a perfect condition in the sense of healthy and normal are expected by all parents. In reality, not all children are born with this condition, so that not a few parents who are shy, lack of confidence and unable to accept the situation of less normal children. One example is a child who has autism. The purpose of this study was to determine how parents' attitudes toward children with autism. Qualitative methods used in this study with data collection techniques are interviews and observation. The results of the study found that parents can accept children diagnosed with autism with a different time period from one another. This can be seen from how the subject understands the child's condition as it is good, positive, negative, strengths and weaknesses of the child and understands children's habits in their daily life such as realizing what children can and cannot do, understanding the causes of bad and good behavior done by children.
\end{abstract}

Keywords: Autistic Child, Parental Aacceptance Attitude

\begin{abstract}
Abstrak
Anak yang terlahir dengan keadaan sempurna dalam artian sehat dan normal sangat diharapkan oleh semua orang tua. Kenyataannya, tidak semua anak terlahir dengan kondisi demikian, sehingga tidak sedikit orang tua yang malu, kurang percaya diri dan tidak dapat menerima keadaan anak yang kurang normal. Misalnya anak yang mengidap autisme. Penelitian ini bertujuan untuk mengetahui bagaimana sikap penerimaan orang tua terhadap anak penyandang autis. Metode kualitatif dipakai dalam penelitian ini dengan teknik pengumpulan datanya adalah wawancara dan observasi. Hasil penelitian didapati bahwa orangtua dapat menerima anak yang didiagnosa menyandang autis dengan jangka waktu yang berbeda satu dengan yang lainnya. Pasangan orang tua yang lengkap (suami istri) berbeda dengan orang tua single parent dalam proses penerimaan anak autis. Hal ini terlihat dari bagaimana subjek memahami kondisi anak apa adanya baik itu tingkah laku positif, negatif, kelemahan dan kelebihan yang anak miliki, serta memahami kebiasaan-kebiasaan anak dalam kesehariannya. Seperti menyadari apa yang telah dapatdan yang belum dilakukan oleh anak dan memahami munculnya perilaku anak yang baik dan buruk.
\end{abstract}

Kata Kunci: Anak Autis, Sikap penerimaan orang tua, 


\section{Pendahuluan}

Dalam kehidupan berkeluarga, kehadiran anak merupakan momen yang dinantinantikan oleh pasangan suami istri dan itu menjadi suatu kebahagian tersendiri. Kehadiran anak bukan saja untuk mempererat hubungan cinta kasih suami dan istri tetapi juga sebagai penerus keturunan dalam keluarga. Pada umumnya, dalam menantikan kehadiran seorang anak orang tua berharap anaknya lahir dalam kondisi yang sehat dan tidak mengalami kondisi yang tidak normal. Masalah akan terjadi jika apa yangdiharapkan tidaklah sesuai dengan kenyataan, dimana anak yang diimpikan selama ini lahir dengan keadaan yang tidak normal seperti mengidap autis.

Autis merupakan gangguan pervasive dengan ciri fungsi yang abnormal dalam interaksi sosial, komunikasi dan perilaku. ${ }^{1}$ Susanto berpendapat bahwa autisme, salah satu bentuk gangguan tumbuh kembang, di mana ada kelainan syaraf-syaraf tertentu yang menyebabkan fungsi otak tidak bekerja secara normal sehingga mempengaruhi tumbuh kembang, kemampuan komunikasi, dan interaksi sosial seseorang. ${ }^{2}$ Maka orang tua harus mengambil peran penting dalam proses perkembangan anak dan memperhatikan segala yang menajdi hak anak. Orang tua juga harus memberikan dukungan dalam artian memberikan pendidikan yang memadai baik formal maupun non formal bagi sang anak sehingga anak autis dapat tertolong dalam perkembangan interaksi sosialnya. Selain itu, bentuk penerimaan orang tua terhadap anak autis adalah dengan memperhatikan pemenuhan kebutuhan dasar anak yaitu kebutuhan fisiologis, rasa aman, rasa memiliki dan kasih sayang, penghargaan, rasa ingin tahu, estetis, pertumbuhan, dan aktualisasi diri. ${ }^{3}$ Jadi, dapat disimpulkan bahwa autis adalah suatu gangguan perkembangan yang ciri utamanya ditunjukkan dengan adanya gangguan komunikasi, interaksi sosial dengan orang lain, dan tumbuh kembang anak.

Pada penelitian sebelumnya yang dilakukan oleh Rachmayanti dan Zulkaida ${ }^{4}$ dijelaskan bahwa ada orangtua yang dapat menerima kenyataan bahwa anak mereka menyandang autis dan penerimaan orangtua sangat mempengaruhi perkembangan anak autisme dikemudian hari. Sedangkan sikap orangtua yang tidak dapat menerima kenyataan bahwa anaknya memiliki gangguan autisme akan sangat buruk dampaknya, karena hal tersebut hanya akan membuat anak autis merasa tidak dimengerti, merasa ditolak, sehingga berdampak pada perilaku anak yang sulit diatasi oleh orangtua. Penelitiaan lain yang dilakukan oleh Pancawati ${ }^{5}$ menjelaskan bahwa tekanan psikologis yang dialami menjadikan orangtua tidak dapat menerima kondisi anak yang menderita autis sehingga berakibat pada kurangnya pemberian dukungan secara emosional,kurang menstimulasi anak untuk berkembang, kurang memperhatikansemua kebutuhan anak serta tidak selalu menjaga anak.

Penolakan orang tua terhadap anak autis dapat berangsur-angsur menjadi penerimaan apabila orang tua dapat melepaskan gambaran ideal tentang anak yang diharapkan. Sebagai contoh, Dyah Puspita seorang ibu yang mempunyai putra tunggal penyandang autisme mengakui bahwa keberhasilan proses terapi autis sangat tergantung

${ }^{1}$ Ririn Pancawati, "Penerimaan Diri Dan Dukungan Orangtua Terhadap Anak Autis" 1, no. 1 (2013): 38-47.

2Sigit Eko Susanto, "Penerimaan Orang tua terhadap Kondisi Anaknya yang Menyandang Autisme di Rumah Terapis Little Star" 9, no. 2 (2014): 13.

3Jendriadi Banoet, Beatriks Novianti Kiling-Bunga, and Indra Yohanes Kiling, "Karakteristik

Prososial Anak Autis Usia Dini Di Kupang," Jurnal PG- - PAUD Trunojoyo 3, no. 1 (2016): 1-8.

4Sri Rachmayanti and Anita Zulkaida, "Penerimaan Diri Orangtua Terhadap Anak Autisme Dan Peranannya Dalam Terapi Autisme" 1, no. 1 (2007): 11.

${ }^{5}$ Pancawati, "Penerimaan Diri dan Dukungan Orangtua Terhadap Anak Autis" 
pada bagaimana sikap orang tua dalam menerima kondisi anaknya dari pada sikap penolakan, karena hanya akan menambah beban pada orang tua. ${ }^{6}$

Berdasarkan data dari Forum Komunikasi Keluarga Anak dengan Kecacatan Nusa Tenggara Timur (FKKAD NTT), jumlah penyandang disabilitas di NTT mencapai 10.000 orang lebih. Ada 3.000 orang di antaranya mengikuti pendidikan SD luar biasa (SDLB), SMP luar biasa (SMPLB) dan SMA luar biasa (SMALB). Selebihnya belum Salah jenis kecacatan yang dimaksud adalah autis. ${ }^{7}$ Salah satu kunci keberhasilan keluarga atau orangtua dalam menerima kondisi anak autisadalah dengan menerima keterbatasan-keterbatasan yang ditunjukan sang anak. Sikap positif seperti ini menunjukkan bahwa orang tua anak tersebut telah mencapai titik kedewasaan hidupnya dengan mengakui nilai-nilai seseorang dan kelemahan-kelemahan tanpa harus menyalahkan orang lain atau diri sendiri. Orangtua yang mampu menerima kekurangan atau kelainan yang terjadi pada anaknya berarti mampu menjadi teman, sahabat, dan guru yang baik bagi diri sendiri, anak maupun keluarganya. Penerimaan diri orangtua terhadap kondisi anak yang menderita autis dapat membantu anak menjalani hidupnya dengan lebih baik. ${ }^{8}$

Penulis merumuskan masalah penelitian adalah bagaimana sikap orang tua dalam menerima anak autis di Kecamatan Kelapa Lima, Kota Kupang? Dan tujuan penelitiannya adalah untuk mengetahui upaya penerimaan orangtua terhadap anak autis.

\section{Autisme}

Autisme berasal dari kata "autos" yang artinya sendiri dan "isme" yang berarti satu aliran sehingga dapat diartikan sebagai suatu paham tertarik pada dunianya sendiri. Autisme pertama kali ditemukan oleh Leo Kanner pada tahun 1943. Istilah ini dipakai karena anak yang mengidap gejala autisme seringkali memang terlihat seperti seorang yang hidup sendiri. ${ }^{9}$ Autis adalah gangguan perkembangan pada masa kanak-kanak dengan manifestasi interaksi sosial dan imajinatif yang rusak. Selain itu, autis merupakan gangguan perkembangan pervasif yang ditandai dengan keterlambatan dan gangguan yang parah pada beberapa area perkembangan seperti pada interaksi sosial, komunikasi dengan orang lain, perilaku bermain, aktivitas sosial dan minat sehari-hari. ${ }^{10}$

Autisme disebabkan oleh beberapa faktor yaitu faktor genetik, pendarahan pada awal kehamilan, obat-obatan yang dikonsumsi pada masa kehamilan, gangguan pernapasan, anemia, infeksi yang mengakibatkan fungsi sel otak terganggu, keracunan logam berat, autoimun. Anak dengan autisme biasanya melakukan gerakan berulang-ulang (stereotipik) tanpa tujuan, membenturkan kepala dengan letupan emosi, tidak mampu melakukan kontak mata, dan jika mampu melakukan kontak mata akan disertai dengan sikap agresif dan letupan emosi. ${ }^{11}$

Anak autis juga dikategorikan dalam beberapa tipe yakni Childhood Disintegrative Disorder, PDD-NOS (pervasive Development Disorder, Not Otherwise Spesified), Rett's Syndrome (Sindroma Rett) merupakan gangguan autistik pada anak yang terjadi karena adanya

\footnotetext{
"Susanto, "Penerimaan Orang tua terhadap Kondisi Anaknya yang Menyandang Autisme di Rumah Terapis Little Star."

7Jendriadi Banoet, Beatriks Novianti Kiling-Bunga, and Indra Yohanes Kiling, "Karakteristik Prososial Anak Autis Usia Dini Di Kupang" (2016): 9.

8Susanto, "Penerimaan Orang tua terhadap Kondisi Anaknya yang Menyandang Autisme di Rumah Terapis Little Star."

9Pancawati, "Penerimaan Diri dan Dukungan Orangtua Terhadap Anak Autis"

${ }^{10}$ Lusi Nuryanti, Psikologi Anak, Jakarta: PT Indeks (2008):15

${ }^{11}$ Deby Zulkarnain Rahadian Syah, Puji Sutarjo, and Inna Riescananda, "Penerimaan Orangtua Terhadap Anak Dengan Autisme Di Pusat Layanan Autis (Pla) Daerah Istimewa Yogyakarta," Media Ilmu Kesehatan 5, no. 3 (December 31, 2016): 206-212.
} 
kelainan generik sehingga berpengaruh pada perkembangan otak dan Sindrom Asperger (Sindrom Asperger) merupakan salah satu dari autisme gangguan spektrum (ASD), namun lebih sering dianggap autisme "high functioning" atau autisme dengan kemampuan yang cukup multifungsi. ${ }^{12}$ Dalam penelitian ini tipe Childhood Disintegrative Disorder yang paling dominan.

\section{Penerimaan Diri}

Penerimaan diri adalah suatu tingkat kemampuan dan keinginan individu untuk hidup dengan segala karakteristik dirinya. Individu yang dapat menerima dirinya diartikan sebagai individu yang tidak bermasalah dengan dirinya sendiri, yang tidak memiliki beban perasaan terhadap diri sendiri sehingga mampu untuk beradaptasi dengan lingkungan. Menurut Carson dan Butcher, penerimaan diri adalah sejauh mana seseorang dapat menyadari dan mengakui karakteristik pribadi dan menggunakannya dalam menjalani kelangsungan hidupnya. ${ }^{13}$ Jadi dari pendapat diatas, dapat disimpulkan bahwa penerimaan diri adalah suatu konsep dimana seseorang memahami akan kekurangan dan kelebihan yang dimilikinya dan mampu menjalani kehidupan ini apa adanya.

Sedangkan penerimaan orang tua merupakan suatu efek psikologis dan perilaku dari orangtua pada anaknya seperti rasa sayang, kelekatan, kepedulian, dukungan dan pengasuhan dimana orangtua tersebut bisa merasakan dan mengekspresikan rasa sayang kepada anaknya. ${ }^{14}$ Orang tua yang anaknya didiagnosa mengalami gangguan autis biasanya belum bisa langsung menunjukan sikap penerimaan terhadap sang anak. Orang tua yang telah mencapai titik menerima keadaan anaknya dengan tenang cenderung mengharapkan yang terbaik sesuai dengan kapasitas dan kemampuan anak mereka. ${ }^{15}$

\section{Sikap Penerimaan Orangtua}

Sikap penerimaan orang tua didefinisikan sebagai ekspresi sederhana dari bagaimana suka atau tidak suka terhadap suatu hal. Pada dasarnya, sikap dapat bersifat positif dan juga bersifat negatif. ${ }^{16}$ Sikap menerima berarti orang tua menyadari bahwa segala kelemahan dan kelebihan yang dimiliki oleh anak harus mendapat tempat dalam hati keluarga dan anak berhak mendapatkan kasih sayang dari orangtuanya.

Tingkat penerimaan orangtua dengan problematika autis sangat dipengaruhi oleh tingkat kestabilan dan kematangan emosi, pendidikan, status sosial ekonomi, dukungan anggota keluarga, struktur dalam keluarga, dan kultur yang melatarbelakanginya. Ketika orang tua menunjukkan kerjasama, kehangatan, saling menghormati, komunikasi yang seimbang, dan penyesuaian terhadap kebutuhan masing-masing akan membantu anak dalam membentuk sikap yang positif. Sebaliknya, bila orang tua menunjukkan koordinasi yang buruk, peremehan yang dilakukan secara aktif oleh orang tua, kurangnya kerjasama dan kehangatan, dan pemutusan hubungan oleh salah satu orang tua merupakan kondisi yang membuat anak menghadapi resiko terjadinya gangguan perkembangan. ${ }^{17}$

\footnotetext{
${ }^{12}$ Rachmayanti and Zulkaida, "Penerimaan Diri Orangtua Terhadap Anak Autisme Dan Peranannya Dalam Terapi Autisme."

${ }^{13}$ Rusdiana, "Hubungan Antara Dukungan Keluarga Dengan Penerimaan Diri Pada Orangtua Yang Memiliki Anak Berkebutuhan Khusus (Abk) Di Samarinda," ejournal. psikologi-fisip-unmul.ac.id. 6, no. 2 (2018): 279-288.

${ }^{14}$ Elizabeth Hurlock, Psikologi Perkembangan (Jakarta: Erlangga, 2002.). 76

${ }^{15}$ T. Safaria, Autisme: Pemahaman Baru UntukHidup Bermakna Bagi Orang Tua (Yogyakarta: Graha Ilmu, 2005).

${ }^{16}$ Susanto, "Penerimaan Orang tua terhadap Kondisi Anaknya yang Menyandang Autisme di Rumah Terapis Little Star."

${ }^{17}$ T. Safaria, Autisme: Pemahaman Baru UntukHidup Bermakna Bagi Orang Tua.
} 
Menurut Puspita bentuk-bentuk penerimaan orang tua adalah sebagai berikut: memahami keadaan anak apa adanya (positif-negatif, kelebihan dan kekurangan), memahami kebiasaan-kebiasaan anak, menyadari apa yang bisa dan belum bisa dilakukan anak, memahami penyebab perilaku buruk atau baik anak-anak, membentuk ikatan batin yang kuat antara orang tua dan anak dan memahami apa sebenarnya anak Autis itu. ${ }^{18}$ Ada tiga faktor yang memengaruhi penerimaan orang tua terhadap anak, yaitu: dukungan dari keluarga besar, faktor ekonomi keluarga dan latarbelakang agama. ${ }^{19}$

\section{Metode Penelitian}

Penelitian ini, penulis mencoba untuk mengeksplorasi lebih dalam tentang proses penerimaan orang tua yang memiliki anak autis dengan menggunakan pendekatan kualitatif. Moleong menyatakan bahwa penelitian kualitatif adalah penelitian yang bermaksud untuk memahami fenomena tentang apa yang dialami oleh subjek penelitian. Misalnya perilaku, persepsi, motivasi, emosional dan lain-lain, secara keseluruhan dan dengan cara deskripsi dalam bentuk kata-kata dan bahasa pada suatu konsep yang alamiah. ${ }^{20}$ Teknik pengumpulan data menggunakan wawancara terstruktur dan observasi, kemudian datanya dianalisis. Miles dan Huberman mengemukakan bahwa aktivitas dalam analisis data kualitatif dilakukan secara interaktif dan berlangsung secara terus menerus sampai tuntas. Aktivitas tersebut adalah reduksi data (data reduction), penyajian data (data display), dan conclusion drawing atau verification. ${ }^{21}$ Pengambilan sampel sebagai sumber data dilakukan secara Purpisive Sampling, ${ }^{22}$ dimana subjek yang akan peneliti pilih dalam penelitian ini adalah 3 pasang orangtua dan 1 perempuan single parent yang lokasi di kecamatan Kelapa Lima, Kota Kupang.

\section{Hasil dan Pembahasan}

\section{Hasil Penelitian}

Penelitian ini bertujuan untuk mengetahui proses orang tua (pasangan suami istri dan single parent) dalam menerima anak dengan gangguan autis. Peneliti berhasil menemukan2 tema, yaitu respon terhadap anak autis dan upaya penerimaan orang tua terhadap anak autis. Berdasarkan indikator memahami anak autis, penulis dapati bahwa subjek 1, 2, 3 (pasangan suami istri) dan subjek 4 (single parent), mengalami hal yang sama ketika mengetahui anak mereka didiagnosa autis. Sikap yang ditunjukkan adalah sedih, bingung, marah, stress, menyalahkan diri sendiri, orang lain dan Tuhan. Selain itu, subjek 3 merasa malu dengan kondisi anaknya sehingga menyerahkan pengasuhan anaknya kepada pembantu rumah tangga. Yang lebih parah lagi adalah subjek 4 yang mengalami depresi karena harus mengasuh anaknya sendiri tanpa seorang suami. Subjek cenderung menghindar dari lingkungan sosial, murung dan merasa putusasa ketika mulai membayangkan masa depan sang anak, siapa yang akan mengasuh anaknya apabila ia meninggal dunia.

Dari indikator menyadari apa yang bisa dan belum bisa dilakukan anak autis, subjek satu (1) menjelaskan bahwa mereka tidak memperlakukan anak dengan keras untuk bekerja karena mereka memahami bahwa anak autis belum mampu untuk melakukan hal-hal diluar kemampuannya. Misalnya ketika anak autis memecahkan piring, subjek 1 tidak akan marah

\footnotetext{
18Susanto, "Penerimaan Orang tua terhadap Kondisi Anaknya yang Menyandang Autisme di Rumah Terapis Little Star."

${ }^{19}$ Elizabeth Hurlock, Psikologi Perkembangan.

${ }^{20}$ Lexy Moleong, Metodologi Penelitian Kualitatif (Bandung: PT. Remaja Rosdakarya, 2008).

${ }^{21}$ Ibid.

22Sugiyono, Penelitian Kulitatif (Bandung: Alfabeta, 2016).
} 
karena mengerti dengan baik kondisi anak autis. Subjek 1 juga mengatakan bahwa kekurangan anak autis adalah sulit untuk tersenyum, tidak berbicara dengan siapapun, selalu menyendiri sehingga sangat sulit untuk bergaul dengan teman sebayanya ketika bermain. Sementara subjek 2 menjelaskan bahwa anaknya belum bisa berbicara, menyendiri, marah tanpa alasan yang jelas sampai membanting mainannya, tidak berespon ketika diajak bicara, sulit untuk tersenyum dan menghindar ketika berada di keramaian. Subjek 3 mengemukakan bahwa anak mereka menghabiskan waktunya untuk mnyendiri, tidak ingin bergaul dan tidak nyambung ketika diajak bicara. Sedangkan subjek 4 menjelaskan bahwa anaknya hanya diam ketika diajak bicara dan tidak ada ekspresi.

Upaya yang dilakukan subjek 1 dalam menerima anak mereka yang autis dimulai dengan memberikan perhatian seperti membantu anak mewarnai, melatih anak berbicara, mengajak anak berdoa sebelum makan, menjaga pola makan anak, dan memberikan pujian kepada sang akan ketika berhasil melakukan sesuatu yang diperintahkan. Sedangkan subjek 2 berusaha untuk mengajari anaknyatersenyum, menceritakan kisah-kisah yang ada dalam Alkitab, mengajar anak berdoa dan mengajar anaknya berbicara karena anaknya pernah berbicara kata "keren sekali" hanya sekali dan setelah itu tidak pernah berbicara lagi. Usaha yang dilakukan oleh mengajak anaknya untuk berbicara, berdoa sebelum makan dan memberikan kasih saya dengan cara memeluk dan mencium serta memberikan pujian kepada anaknya yang autis. Sementara subjek 3 dan 4 membawa anak refreshing di pantai, belajar mengenal huruf dan angka, membelikan buku gambar, alat tulis, mengajak anaknya untuk keluar rumah untuk bermain dengan teman sebayanya dan yang paling penting adalah mencurahkan kasih sayang kepada anaknya.

Berdasarkan indikator pemahaman orang tua mengenai penyebab perilaku buruk atau baik anak autis, Subejk 1,2,3 dan 4 menjelaskan bahwa perilaku buruk yang sering ditunjukkan oleh anak-anak mereka adalah sering marah atau menangis tanpa alasan yang jelasdan membanting benda yang dipegang. Berkaitan dengan indikator mengenai membentuk ikatan batin yang kuat, 4 subjek menjelaskan bahwa mereka berusaha sebaik mungkin membangun komunikasi dengan anak mereka, memberikan perhatian dan kasih sayang yang cukup, tidak memarahi anak ketika melakukan kesalahan, meluangkan waktu bermain bersama anak, mengajak anak keluar dan memberikan pujian ketika anak menunjukkan perkembangan yang positif.

\section{Pembahasan}

Pada umumnya, reaksi yang muncul pertama kali pada orang tua ketika anaknya memiliki permasalahan pada kondisi fisik maupun kesehatan adalah tidak percaya, adanya goncangan batin dalam dirinya, dan tidak mempercayai kenyataan yang menimpa anak mereka. ${ }^{23}$ Respon lain yang ditunjukkan adalah penolakan dengan berbagai alasan seperti merasa tidak percaya, sedih, bingung, stress, pasrah dengan keadaan yang dialami, marah pada diri sendiri, orang lain dan Tuhan, serta tidak dapat menerima kenyataan. Sikap seperti ini adalah hal yang wajar dan normal, karena pada dasarnya setiap orangtua menginginkan yang terbaik buat anaknya. Menurut Tong, seorang anak memberikan makna hari depan bagi orangtua, sehingga perjuangan orangtua adalah untuk anak-anak. Karena ada anak, hari depan orangtua ada jaminan. Karena ada anak, masyarakat punya hari depan. ${ }^{24}$ Harapan tersebut hanya sekadar utopia bagi orangtua pada saat mengetahui anaknya terindikasi autis. Mereka membayangkan betapa beratnya membesarkan anak autis

\footnotetext{
${ }^{23}$ Ade Surya Febrianto, dan Ira Darmawanti, "Studi Kasus Penerimaan Seorang Ayah Terhadap Anak Autis," Jurnal Psikologi Teori dan Terapan 7 (2016): 50-61.

24Stephen Tong, Membesarkan Anak Dalam Tuhan (Jakarta: Lembaga Reformed Injili Indonesia, 2000).
} 
sekaligus merasa kasihan terhadap masa depan anaknya. Kontribusi orang tua sangat diperlukan untuk menolong anak autis, sehingga kekuatiran yang ada pada diri orang tua berangsur-angsur diatasi dengan cara yang tepat.

Untuk menolong anak autis, orang tua sebaiknya memahami kebiasaan dan ciri-ciri spesifik yang ditunjukkan anak autis seperti sulit berbicara, tidak merespon ketika diajak bicara, sulit tersenyum, selalu menyendiri, dan tidak mampu bergaul ketika sedang bermain dengan teman sebayanya. Hal ini telah dilakukan oleh orang tua dengan cara terus mengajak anaknya belajar berbicara, melatih anak untuk tersenyum, dan belajar bergaul dengan teman sebaya. Tindakan-tindakan yang telah dilakukan oleh orang tua didasarkan pada pemahaman bahwa orang tua adalah figur pertama dan utama dalam memberikan kasih sayang, perhatian, dan berusaha memahami perkembangan anaknya. Orang tua memainkan peran penting dalam memenuhi kebutuhan dasar anaknya. Kebutuhan akan rasa aman, perhatian, kasih sayang, serta penerimaan secara utuh dan penuh merupakan hak yang anak perlu dapatkan dari orang tuanya. Hal ini tidak hanya diperuntukkan bagi anak normal, namun juga sangat dibutuhkan bagi anak autis. Perhatian yang ekstra dan penerimaan diri yang tulus menjadi energi positif terhadap perkembangan anak. Pemikiran ini searah dengan pendapat John Grey ${ }^{25}$ bahwa bagian yang penting dalam tugas mengasuh anak adalah mencurahkan kasih sayang.

Bersumber pada indikator kesadaran orangtua mengenai apa yang bisa dan belum bisa dilakukan oleh anak autis. Setiap subjek menjelaskan bahwa ketika anak autis melakukan kesalahan seperti memecahkan piring, subjek tidak akan memarahinya karena menyadari bahwa anaknya belum mampu untuk bekerja atau makan sendiri. Begitu pula kebiasaan autis lainnya yang dilakukan anak mereka. Kesadaran terhadap hal-hal yang belum bisa dilakukan oleh anak autis membuat subjek tidak memaksakan kehendak kepada anaknya. Orang tua perlu menerapkan pola asuh yang berbeda dan variatif kepada anak autis. Menurut Santrock, ${ }^{26}$ pengasuhan yang baik membutuhkan waktu dan usaha. Oleh karena itu, orang tua harus mengetahui keunikan yang ada dalam diri anak autis, mempelajari keunikan tersebut untuk menerapkan pola asuh yang tepat demi perkembangan kepribadian anak autis menuju ke arah yang lebih baik.

Indikator selanjutnya adalah pemahaman orang tua mengenai penyebab perilaku baik dan buruk anak autis. Subjek menjelaskan bahwa penyebab perilaku buruk anak autis disebabkan karena fungsi otak tidak normal sehingga mengalami gangguan perkembangan yang kompleks. Bentuk perilaku buruk yang sering ditunjukkan adalah membanting benda yang sedang dipegang ketika marah dan menangis tanpa alasan yang jelas. Berkaitan dengan perilaku yang baik, didapati bahwa anak autis sudah mampu untuk mewarnai, duduk tenang ketika mendengar cerita Alkitab, bernyanyi, berdoa, dan mampu berekspresi ketika mendengarkan musik. Perilaku baik ini ditunjang oleh usaha subjek dalam menghargai, membimbing dan mengembangkan kemampuan yang dimiliki anaknya. Penghargaan yang diberikan orangtua sangat berarti bagi anak autis dalam mengembangkan perilaku yang baik. Sebab manusia adalah makhluk yang paling dihargai Allah dan manusia mempunyai kebutuhan untuk menganggap dirinya makhluk yang berharga. ${ }^{27}$ Artinya, manusia butuh untuk dihargai dan disukai oleh orang lain termasuk

${ }^{25}$ Budi Andayani, "Pentingnya Budaya Menghargai Dalam Keluarga," Buletin Psikologi 10, no. 1 (2002): $1-8$.

26Jhon W. Santrock, Perkembangan Anak, 7th ed., vol. 2 (Jakarta: Penerbit Erlangga, 2007). 174

${ }^{27}$ Robert R. Boehlke, "Sejarah Perkembangan Pikiran dan Praktek Pendidikan Agama Kristen dari Yohanes Amos Commenius Sampai Perkembangan PAK di Indonesia," vol. 2 (Jakarta: BPK. Gunung Mulia, 2016), 30. 
anak autis. Searah dengan hal ini, Maslow menyatakan bahwa pemenuhan kebutuhan untuk dihargai akan membawa anak pada rasa percaya diri, berguna, kuat, dan mampu. ${ }^{28}$

Berkaitan dengan indikator mengenai membentuk ikatan batin yang kuat, orang tua berusaha menjaga keharmonisan dalam menjalin hubungan dengan anak autis. Hal ini dilakukan karena orang tua memahami bahwa anak autis adalah anak yang membutuhkan perhatian dan kasih sayang yang lebih. Selain itu, orangtua perlu mengedukasi orang-orang terdekat untuk memiliki pemahaman dan pengertian yang baik bahwa anak autis adalah anak yang memiliki kekurangan dalam proses perkembangan. Dengan memberikan pengertian yang baik kepada keluarga maka anak autis akan mendapatkan penerimaan secara maksimal sebagai penunjang kemajuan perkembangan kepribadiannya. Anak perlu dikasihi dan diterima, bukan karena anak telah melakukan sesuatu, tetapi karena anak memiliki nilai manusiawi. Jika suasana di keluarga mencakup penerimaan yang bahagia dan memuaskan atas anak-anak, maka anak akan merasa dihargai dan dapat bertahan dengan kuat. Penerimaan itu bukan berarti perilaku mereka yang diterima, tetapi menerima harga diri dan nilai anak itu sendiri. Dengan demikian anak akan merasa senang dan mengalami perkembangan kepribadian yang baik bila diterima. Sebaliknya bila anak hidup dalam lingkungan yang tidak menerima mereka, maka akan timbul jiwa yang penuh ketakutan dan rasa bersalah. Jiwa yang penuh ketakutan dan rasa bersalah yang ada dalam diri anak dapat menghambat perkembangan kepribadiannya. ${ }^{29}$

Dalam penelitian ini juga ditemukan bahwa sikap penerimaan orang tua sangat dipengaruhi oleh tipe autis yang dialami oleh anaknya. Tipe autis yang ditemukan dalam penelitian ini adalah childhood disintegrative disorder. Jenis autis ini paling sulit untuk disembuhkan karena pada umumnya anak mengalami keterlambatan perkembangan bahasa, sosial, dan juga emosi. Menurut Nuryanti ${ }^{30}$ tipe childhood disintegrative disorder merupakan sebuah gangguan pada perkembangan anak yang gejalanya seperti: 1) Gangguan komunikasi dimana anak autis mengalami keterlambatan dalam berbicara, atau sama sekali tidak menunjukkan perkembangan. Tidak menunjukkan adanya keinginan untuk berkomunikasi baik melalui gerak tubuh maupun mimik muka. Tidak berkeinginan untuk memulai sebuah interaksi dengan orang lain dan lebih suka atau sibuk dengan dunianya sendiri. Bila sudah mampu berbahasa, tetapi yang diucapkan tidak memiliki makna yang jelas dan tidak lazim serta diulang-ulang terus-menerus. Tidak menyukai permainan yang imajinatif, sehingga permainan yang dilakukannya kurang bervariasi. 2) Ganguan sosial, anak autis tidak mampu melakukan kontak mata dengan baik, tidak menunjukkan ekpresi wajah, dan gerakan yang dilakukan sebagaimana berinterksi secara normal. Kurang suka bermain, sulit untuk berbaur dengan teman sebaya karena lebih suka sendiri, dan bila bersama dengan teman kurang bisa membina hubungan serta tidak mampu berempati maupun membaca emosi orang lain. 3) Ganguan emosi. Anak-anak dengan childhood disintegrative disorder ini seringkali memperlihatkan luapan emosi yang cukup berlebihan seperti tantrum, ketakutan pada hal-hal tertentu dengan tidak wajar, juga tertawa bahkan menangis tanpa adanya sebab yang jelas. Selain itu, anak sulit berinteraksi, menyendiri ketika bermain dan memiliki emosi yang tidak normal. Contohnya ketika bermain dan mainnya sedikit rusak, anak autis akan marah dan melemparkan mainannya dan tidak mau bermain lagi.

Dalam proses penerimaan terhadap anak autis, subjek 1, 2 dan 3 sudah dapat menerima kondisi anak apa adanya dan berusaha untuk menolong anak mereka. Sedangkan

${ }^{28}$ Budi Andayani, "Pentingnya Budaya Menghargai Dalam Keluarga," Buletin Psikologi 10, no. 1 (2002): 8 .

29John M. Drescher, Tujuh Kebutuhan Anak (Jakarta: BPK. Gunung Mulia, 2009). 27.

${ }^{30}$ Nuryanti Lusi, Psikologi Anak (Jakarta: PT Indeks, 2008). 35 
subjek 4 yakni perempuan single parent belum sepenuhnya menerima kondisi anaknya. Hal ini dikarenakan adanya perasaan stres yang masih ada sampai saat ini, sebab ia harus mengasuh anaknya sendiri tanpa pendampingan seorang suami. Selain itu, faktor ekonomi juga menjadi salah satu alasan mengapa subjek masih belum sampai pada titik penerimaan anak autis. Menurut Gunarsa, kemampuan penyesuaian diri dari ibu akan memengaruhi psikologis dari ibu sendiri dan juga perkembangan anak autis. Ibu yang mampu menyesuaikan diri dengan baik akan memiliki kondisi psikologis yang sehat dan akan berdampak positif bagi perkembangan anaknya. Sebaliknya, ibu yang tidak mampu menyesuaikan diri dengan baik akan memiliki kondisi psikologis yang tidak sehat dan akan berdampak negatif bagi perkembangan anaknya. ${ }^{31}$ Jika orang tua telah benar-benar menyadari dan memahami kondisi anaknya dan menerima apapun yang terjadi, maka akan muncul sikap penerimaan terhadap kekurangan serta keterbatasan yang ada pada anak mereka.

\section{Implikasi}

Sebagai orang tua yang memiliki anak autis sebaiknya terus memantau perkembangan anak tersebut. Orang tua juga perlu membawa anak tersebut kepada dokter yang menangani kesehatan anak autis secara berkelanjutan dengan tujuan agar orang tua mengetahui secara pasti bagaimana kondisi kesehatan anaknya baik secara fisik maupun psikis. Hal ini bertujuan agar pengasuhan orang tua terhadap anak autis lebih terarah dan mendapatkan hasil yang lebih maksimal.

Orang tua sebagai pendamping harus membekali diri dengan pengetahuan yang memadai mengenai autisme, sehingga dalam perjalanan penanganannya orang tua dapat membantu anak autis dengan berbagai macam terapi maupun keterampilan pendukung lainnya, agar anak tersebut tidak merasa diabaikan. Selain itu, penerimaan orang tua menjadi faktor penting dalam menunjang tumbuh kembang anak autis yang lebih baik. Pendampingan dan perhatian yang diberikan menjadi motivasi bagi anak, sehingga anak lebih percaya diri dalam menjalani aktivitas sehari-hari. Perlakuan orang tua terhadap anak autis layaknya anak normal akan memberi dampak yang positif terhadap perkembangannya secara fisik dan psikis. Sebaliknya, orang tua yang tidak dapat menerima kondisi anak autis akan memperburuk kondisi anak tersebut.

\section{Kesimpulan}

Berdasarkan hasil penelitian, maka penulis dapat menyimpulkan bahwa sikap awal yang ditunjukkan orang tua ketika anak didiagnosa mengalami autis yaitu keadaan bingung, sedih dan stress sehingga membuat subjek menjadi marah dan pasrah dengan keadaan yang dialami. Di samping itu, penerimaan orang tua terhadap anak autis juga ditunjukkan melalui sikap orang tua yang selalu berusaha mengajak anak autis untuk berbicara, bergaul dengan teman sebayanya ketika bermain, mengembangkan potensi yang dimiliki anak autis seperti mewarnai gambar dan mengajarkan anak autis tentang pengenalan huruf dan angka.

Dalam proses penerimaan terhadap anak autis, orang tua harus terbuka untuk menerima anak apa adanya dan memberikan perhatian penuh sebagai bentuk penguatan sehingga anak dapat menunjukkan kemampuan yang dimiliki sebab ada orang yang selalu mendukungnya. Proses penerimaan orang tua terhadap anak autis yang memiliki pasangan juga ditemukan jauh berbeda dengan proses penerimaan yang dilakukan oleh perempuan single parent. Pasangan suami isteri dalam proses penerimaan saling dukungan dalam

\footnotetext{
${ }^{31}$ Singgih Gunarsa, Psikologi Untuk Keluarga (Jakarta: BPK Gunung Mulia, 2003). 23.
} 
mengasuh anak autis. Sedangkan proses penerimaan perempuan single parent sangat mengalami kesulitan karena harus merawat anaknya tanpa seorang suami.

\section{Rekomendasi untuk Penelitian Lanjutan}

Bagi peneliti selanjutnya diharapkan untuk mengkaji mengenai posisi orang tua tunggal dalam mengasuh anak autis.

\section{Rujukan}

Ade Surya Febrianto, dan Ira Darmawanti. "Studi Kasus Penerimaan Seorang Ayah Terhadap Anak Autis." Jurnal Psikologi Teori dan Terapan 7 (2016): 50-61.

Andayani, Budi. "Pentingnya Budaya Menghargai Dalam Keluarga." Buletin Psikologi 10, no. 1 (2002): 1-8.

Banoet, Jendriadi, Beatriks Novianti Kiling-Bunga, and Indra Yohanes Kiling. "Karakteristik Prososial Anak Autis Usia Dini Di Kupang" (2016): 9.

Elizabeth Hurlock. Psikologi Perkembangan. Jakarta: Erlangga, n.d.

Jendriadi Banoet, Beatriks Novianti Kiling-Bunga, and Indra Yohanes Kiling. "Karakteristik Prososial Anak Autis Usia Dini Di Kupang." Jurnal Pg- - Paud Trunojoyo 3, no. 1 (2016): 1-8.

Jhon W. Santrock. Perkembangan Anak. 7th ed. Vol. 2. Jakarta: Penerbit Erlangga, 2007.

John M. Drescher. Tujuh Kebutuhan Anak. Jakarta: BPK. Gunung Mulia, 2009.

Lexy Moleong. Metodologi Penelitian Kualitatif. Bandung: PT. Remaja Rosdakarya, 2008.

Nuryanti Lusi. Psikologi Anak. Jakarta : PT. Indeks: PT. Indeks, 2008.

Rachmayanti, Sri, and Anita Zulkaida. "Penerimaan Diri Orangtua Terhadap Anak Autisme Dan Peranannya Dalam Terapi Autisme" 1, no. 1 (2007)

Rahadian Syah, Deby Zulkarnain, Puji Sutarjo, and Inna Riescananda. "Penerimaan Orangtua Terhadap Anak Dengan Autisme Di Pusat Layanan Autis (Pla) Daerah Istimewa Yogyakarta." Media Ilmu Kesehatan 5, no. 3 (December 31, 2016): 206-212.

Ririn Pancawati. "Penerimaan Diri Dan Dukungan Orangtua Terhadap Anak Autis" 1, no. 1 (2013): 38-47.

Robert R. Boehlke. "Sejarah Perkembangan Pikiran dan Praktek Pendidikan Agama Kristen dari Yohanes Amos Commenius Sampai Perkembangan PAK di Indonesia." Jakarta : BPK. Gunung Mulia, 2016.

Rusdiana,. "Hubungan Antara Dukungan Keluarga Dengan Penerimaan Diri Pada Orangtua Yang Memiliki Anak Berkebutuhan Khusus (Abk) Di Samarinda." ejournal. psikologifisip-unmul.ac.id. 6, no. 2 (2018): 9-288.

Singgih Gunarsa. Psikologi Untuk Keluarga. Jakarta: BPK Gunung Mulia, 2003.

Stephen Tong. Membesarkan Anak Dalam Tuhan. Jakarta: Lembaga Reformed Injili Indonesia, 2000.

Sugiyono. Penelitian Kulitatif. Bandung: Alfabeta, 2016.

Susanto, Sigit Eko. "Penerimaan Orang tua terhadap Kondisi Anaknya yang Menyandang Autisme di Rumah Terapis Little Star" 9, no. 2 (2014): 13.

T. Safaria. Autisme: Pemahaman Baru Untuk Hidup Bermakna Bagi Orang Tua. Yogyakarta: Graha Ilmu, 2005. 